\title{
Strategi Kepala Sekolah dalam Membangun Mutu Pendidikan di MTsN Model Pare, Kediri
}

\author{
A'an Yusuf Khunaifi \\ Sekolah Tinggi Ilmu Syari’ah Faqih Asy'ari Kediri, Indonesia \\ e-mail: aankhunaifie@gmail.com
}

\begin{abstract}
The demand of quality education the more days pass more gain strength. This phenomenon appear along with the condition of peoples needs growing rapidly. That indispensable priscipal professional, were able to establish that the quality of education quality and considered superior public interest.

The focus of this study are three things, that is: a) principal behavior in the build quality of education. b) strategy principals in building the quality of education. to answer the focus of the study, the researchers used a qualitative approach, nid of case studies.

Methods of data collection use include: a) deep interview. b) oservation. c) study documentation. Data from the three techniques are organized, interpreted, and analyzed repeatedly. To avoid mistakes, then held data validity checking using the method of: a) triangulation between data sources, comparing data from interviews. b) checking the accuracy of information to the informant. c) discuss and consult data by the competent authorities.

The results of this study found: 1) behavior of the principals in building a quality of education that is: a) motivate. b) establish good communation and warm. c) in volve all members of the school, and example to the school community in an effort to build the quality of education. 2) strategy principal in building the quality of education that is: a) build a strong team work and soulid. b) build a family. c) to support and facilitate teachers in the development of quality and competene. d) the division of duties and performance to match the capabilities of each subordinate. e) working closely with other agencies. f) to collaoration with the mass media. g) having a clear quality targets.
\end{abstract}

Keyword: Leadership strategy, quality education

\section{Pendahuluan}

Sekolah sebagai lembaga pendidikan formal yang bertujuan mencetak sumber daya manusia berkualitas, memikul beban berat yang harus dipertanggung jawabkannya kepada pemerintah, masyarakat, bangsa dan negara. Hal ini disebabkan keberhasilan pendidikan di suatu negara sangat dipengaruhi oleh keberhasilan penyelenggaraan program pendidikan yang berlangsung di tingkat sekolah, terutama di tingkat sekolah dasar karena merupakan pijakan bagi keberhasilan pendidikan di jenjang berikutnya.

Demi tercapainya tujuan pendidikan yang diharapkan, sekolah harus dikelola oleh orang-orang yang profesional serta memiliki dedikasi tinggi terhadap pendidikan. Dalam hal ini, kepala sekolah sebagai pemimpin pendidikan di tingkat sekolah mempunyai tugas dan tanggung jawab yang sangat berat apabila dihubungkan dengan peranan sekolah sebagai lembaga penyelenggara pendidikan yang bertujuan mencetak sumber daya manusia berkualitas. Oleh karena itu kepala sekolah dituntut untuk mempunyai pengetahuan, kemampuan dan keterampilan yang memadai sehingga akan membantunya dalam menjalankan tugas dan tanggung jawabnya.

Kepala sekolah memegang peranan yang sangat penting dalam menentukan keberhasilan penyelenggaraan suatu program pendidikan, karena selain sebagai pengelola dia juga berperan sebagai supervisor di sekolah yang dipimpinnya. Banyak pihak yang berpendapat bahwa kepala sekolah merupakan pemegang kunci keberhasilan sekolah karena segala aktivitas dan kegiatan yang berlangsung di sekolah berada di bawah tanggung jawabnya. kepala sekolah di samping ia sebagai seorang supervisor, kepala sekolah juga menjadi seorang pendidik yang profesional yang berperan 
merencanakan dan melaksanakan proses pembelajaran, hal ini dinyatakan dalam UndangUndang Nomor 20 tahun 2003 tentang Sistem Pendidikan Nasional pasal 39 ayat 2 yang berbunyi “ pendidik merupakan tenaga profesional yang bertugas merencanakan dan melaksanakan proses pembelajaran, menilai hasil pembelajaran, melakukan bimbingan dan pelatihan, serta melakukan penelitian dan pengabdian kepada masyarakat, terutama pada pendidik di perguruan tinggi ".

Jabatan kepala sekolah bukan jabatan yang bisa diisi oleh sembarang orang karena jabatan ini merupakan jabatan formal yang memerlukan keterampilan serta latar belakang pendidikan tertentu, walaupun pada kenyataannya jabatan ini banyak diisi oleh orang-orang yang tidak mempunyai persyaratan tersebut. ${ }^{1}$

Mengingat betapa penting peranan kepala sekolah dalam pencapaian tujuan pendidikan, maka kemampuan profesional serta kualitas kinerjanya harus ditingkatkan secara terus menerus dan berkesinambungan. Sebagai seorang pemimpin ada beberapa syarat yang harus dimiliki oleh seorang kepala sekolah, sebagaimana diungkapkan Noris (2000) bahwa disarankan kepala sekolah memiliki beberapa kemampuan sebagai seorang pemimpin, yaitu: (1) Seorang pemimpin yang memiliki pengetahuan yang luas tentang pendidikan; (2) Kemampuan menganalisis situasi sekarang berdasarkan apa yang seharusnya; (3) Mampu mengidentifikasi masalah; dan (4) Mampu mengonsepkan arah baru untuk perubahan. ${ }^{2}$

Berdasarkan pendapat di atas, kepala sekolah dituntut untuk mempunyai pengetahuan dan kemampuan manajerial yang tinggi agar dapat mengelola sekolah secara efektif. Selain itu kepala sekolah juga dituntut untuk mempunyai jiwa inovatif sehingga terbuka terhadap perubahan serta mampu memprediksikan apa yang akan dihadapi pada masa mendatang. Untuk itu, kepala sekolah hendaknya selalu berusaha meningkatkan pengetahuan dan keterampilannya yang akan membawa pengaruh besar terhadap kemampuannya di dalam mengelola

\footnotetext{
${ }^{1}$ Wahjosumidjo, Kepemimpinan Kepala Sekolah, (Jakarta: Raja Grafindo, 1999), h. 84.
}

sekolah sehingga mampu mengembangkan sekolah berkualitas seperti yang diharapkan.

Secara lebih jelas, Wahjosumidjo mengemukakan bahwa kepala sekolah selaku pemimpin memerlukan: (1) Kemampuan memimpin; (2) Kompetensi administratif dan pengawasan; (3) Pemahaman terhadap tugas dan fungsi kepala sekolah; (4) Pemahaman terhadap peran sekolah yang bersifat multi function; (5) Tugas pokok kepala sekolah dalam rangka pembinaan program pengajaran, sumber daya manusia, kesiswaan, dana, sarana dan fasilitas, serta hubungan kerja sama sekolah dengan masyarakat. Selain sebagai pemimpin, kepala sekolah juga berperan sebagai supervisor yang dituntut untuk mampu memberikan bimbingan, bantuan, pengawasan dan penilaian pada masalah-masalah yang berhubungan dengan teknis pendidikan. ${ }^{3}$

Kepala sekolah memegang peranan yang sangat penting dalam menentukan keberhasilan penyelenggaraan suatu program pendidikan, karena selain sebagai pengelola dia juga berperan sebagai supervisor di sekolah yang dipimpinnya. Banyak pihak yang berpendapat bahwa kepala sekolah merupakan pemegang kunci keberhasilan sekolah karena segala aktivitas dan kegiatan yang berlangsung di sekolah berada di bawah tanggung jawabnya. kepala sekolah di samping ia sebagai seorang supervisor, kepala sekolah juga menjadi seorang pendidik yang profesional yang berperan merencanakan dan melaksanakan proses pembelajaran, hal ini dinyatakan dalam UndangUndang Nomor 20 tahun 2003 tentang Sistem Pendidikan Nasional pasal 39 ayat 2 yang berbunyi “ pendidik merupakan tenaga profesional yang bertugas merencanakan dan melaksanakan proses pembelajaran, menilai hasil pembelajaran, melakukan pembimbingan dan pelatihan, serta melakukan penelitian dan pengabdian kepada masyarakat, terutama pada pendidik di perguruan tinggi".

Berdasarkan pendapat di atas, kepala sekolah dituntut untuk mempunyai pengetahuan dan kemampuan manajerial yang tinggi agar dapat mengelola sekolah secara efektif. Selain itu kepala

\footnotetext{
${ }^{2}$ M. Saroni M, Manajemen Sekolah Kiat Menjadi Pendidik Yang Kompeten, (Jogjakarta: Ar-Ruzz Media, 2002), h. 23

${ }^{3}$ Wahjosumidjo, Kepemimpinan., h. 11.
} 
sekolah juga dituntut untuk mempunyai jiwa inovatif sehingga terbuka terhadap perubahan serta mampu memprediksikan apa yang akan dihadapi pada masa mendatang. Untuk itu, kepala sekolah hendaknya selalu berusaha meningkatkan pengetahuan dan keterampilannya yang akan membawa pengaruh besar terhadap kemampuannya di dalam mengelola sekolah sehingga mampu mengembangkan sekolah berkualitas seperti yang diharapkan.

Oleh karena itu, untuk meningkatkan kualitas mutu pendidikan, maka kepala sekolah atau madrasah diberi kebebasan seluas-luasnya untuk mengambil inisiatif dan berkreasi. Seorang kepala lembaga pendidikan tidak mungkin akan mengorbankan mereka yang dipimpinnya. Siapapun tatkala diberi amanah, tidak terkecuali pimpinan lembaga pendidikan, akan menunjukkan bahwa dirinya mampu, cakap, dan berjuang untuk meraih yang terbaik. Kepala sekolah atau madrasah yang terlalu diatur oleh birokrasi pendidikan maka justru tidak akan menjadi kreatif, sehingga aturan yang berlebihan itu sebenarnya akan menghambat kemajuan.

Pengaruh kepala sekolah yang profesional juga berdampak pada animo masyarakat yang berbondong-bondong menyekolahkan anak mereka ke lembaga madrasah. Sejalan dengan pra-penelitian yang peneliti lakukan di MTsN Model Pare menunjukkan bahwa alasan yang mendasari pilihan masyarakat menyekolahkan anaknya ke lembaga pendidikan berbasis agama terlebih di MTsN Model Pare, berdasarkan dari hasil survei dari data dan keterangan beberapa sumber menunjukkan bahwa alasan orang tua menyekolahkan anaknya secara berurutan adalah; (a) sistem pendidikan yang mengombinasikan mata pelajaran umum dan mata pelajaran keagamaan bahkan ada kajian kitab kuning seperti mabadi fiqh, (b) ada program kelas akselerasi dan kelas unggulan, (c) disiplin tinggi dan dedikasi para guru cukup tinggi, (d) prestasi lulusannya cukup tinggi terbukti dengan hasil pararel peringkat madrasah tingkat se-kab. Kediri pada tahun 2015 dan 2016 MTsN Model Pare menduduki peringkat pertama, (e) tersedianya laboratorium cukup lengkap, (f) metode pengajarannya cukup baik dan

\footnotetext{
${ }^{4}$ Hasil wawancara dengan kepala sekolah MTsN Model Pare oleh bapak Jamiluddin, pada tanggal 8 Agustus 2016.
}

mudah diterima, (g) Sekolah Negeri, dan (h) tempatnya bagus dan strategis karena berada di pusat kota pare mudah mengakses berbagai informasi. ${ }^{4}$

Di samping itu keunggulan madrasah sekarang ini di antaranya adalah memiliki keterpaduan moralitas dan intelektualitas yang ditanamkan kepada siswa dengan dukungan seluruh civitas akademika yang ada dilingkungan madrasah. Masyarakat yang merasa khawatir terhadap keselamatan putra-putrinya meyakini bahwa dengan menyekolahkan pada lembaga yang berbasis agama merupakan upaya preventif yang tepat untuk melindungi generasi bangsa dari ancaman penyakit masyarakat terlebih dengan kemajuan teknologi yang semakin memudahkan budaya barat masuk ke Indonesia dengan pengaruh yang cukup signifikan terhadap tumbuh kembang anak didik kita. Hal ini sesuai dengan firman Allah SWT dalam surat AnNisa' ayat 9:

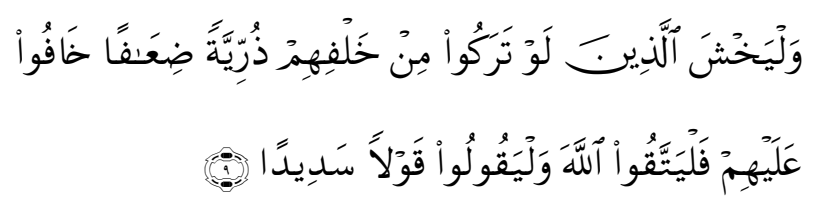

Artinya: "Dan hendaklah takut kepada Allah orang-orang yang seandainya meninggalkan di belakang mereka anak-anak yang lemah, yang mereka khawatir terhadap (kesejahteraan) mereka. oleh sebab itu hendaklah mereka bertakwa kepada Allah dan hendaklah mereka mengucapkan Perkataan yang benar". ${ }^{5}$

Ayat di atas mengisyaratkan bahwa pendidikan sangat penting membekali manusia dalam mempengaruhi bahtera kehidupan dengan kekuatan iman dan ilmu. Oleh karena itu, pilihan masyarakat pada lembaga berbasis agama menguatkan keyakinan bahwa agama mampu menjadi alat untuk memperbaiki keadaan, mampu menjadi perekat, penjaga (control) terhadap penyimpangan norma serta bekal hidup yang lebih baik. Tujuan penelitian ini adalah untuk mendeskripsikan dan menganalisis perilaku kepala sekolah membangun mutu pendidikan studi kasus di MTsN Model Pare Kab. Kediri serta untuk mendeskripsikan dan menganalisis bagaimana strategi kepala sekolah dalam membangun mutu pendidikannya.

\footnotetext{
5 Departemen Agama, Al-Qur'an dan Terjemahnya, (Jakarta: CV. Khatoda, 2005), h. 101.
} 


\section{Landasan Teori}

\section{Pengertian kepala sekolah}

Menurut kamus besar bahasa Indonesia kepala diartikan kepala atau pemimpin dalam suatu organisasi atau sebuah lembaga. Sedangkan sekolah adalah sebuah lembaga di mana menjadi tempat menerima dan memberi pelajaran. ${ }^{6}$

"leadership is interpersonal influence exercised in a situasion, and directed, through the communication process, toward the attainment of specified goal or goal" 7

Istilah kepemimpinan telah didefinisikan oleh mereka bahwa kepemimpinan adalah proses mempengaruhi aktivitas-aktivitas sebuah kelompok yang diorganisasi ke arah pencapaian tujuan. Kepemimpinan dapat didefinisikan sebuah proses memberi arti (pengarahan yang berarti) terhadap usaha kolektif dan mengakibatkan kesediaan untuk melakukan usaha yang diinginkan untuk mencapai sasaran. ${ }^{8}$ Definisi di atas dapat dijelaskan kepemimpinan adalah perilaku seseorang dalam mempengaruhi aktivitas bawahan agar bersedia melakukan sesuatu untuk mencapai tujuan organisasi.

\section{Tugas dan Fungsi Kepala Sekolah}

Tugas utama sekolah sebagai pemimpin adalah mengatur situasi, mengendalikan kegiatan kelompok organisasi atau lembaga dan menjadi juru bicara kelompok. ${ }^{9}$ Dalam rangka melaksanakan tugas dan fungsinya, terutama dalam rangka memberdayakan masyarakat dan lingkungan sekitar, kepala sekolah dituntut untuk mampu berperan ganda, baik sebagai catalyst, solution giver, process helpers, and resources linker:

a. Catalyst: berperan meyakinkan orang lain tentang perlunya perubahan menuju kondisi yang lebih baik.

b. Solution Giver: berperan mengingatkan tujuan akhir dari perubahan.

c. Process Helper: berperan membantu kelancaran proses perubahan, khususnya menyelesaikan

\footnotetext{
${ }^{6}$ Kamus Besar Bahasa Indonesia, Departemen Pendidikan dan Kebudayaan Republik Indonesia (Jakarta: Perum Balai Pustaka, 1988), h. 420.

7 Weschler Tannenbaun dan Massarik. F, Leadership and Organisation, (New York: McGraw-Hill, 1961), h. 24.

${ }^{8}$ Ibid, h. 24
}

masalah dan membina hubungan antara pihakpihak yang terkait.

d. Resource linkers: berperan menghubungkan orang dengan sumber dana yang diperlukan. ${ }^{10}$

Sehubungan dengan MBS (Manajemen Berbasis Sekolah), kepala sekolah dituntut senantiasa meningkatkan efektivitas kerja. Dengan begitu MBS sebagai paradigma baru pendidikan dapat memberikan hasil yang memuaskan. Kinerja kepala sekolah dalam kaitannya dengan MBS adalah segala upaya yang dilakukan dan hasil yang dapat dicapai oleh kepala sekolah dalam mengimplementasikan MBS disekolahnya untuk mewujudkan tujuan pendidikan secara efektif dan efisien. Sehubungan dengan itu, kepala sekolah yang efektif dalam MBS dapat dilihat berdasarkan kriteria sebagai berikut:

a. Mampu memberdayakan guru-guru untuk melaksanakan proses pembelajaran dengan baik, lancar dan produkti.

b. Dapat menyelesaikan tugas dan pekerjaan sesuai dengan waktu yang telah ditetapkan.

c. Mampu menjalin hubungan yang harmonis dengan masyarakat sehingga dapat melibatkan mereka secara aktif dalam rangka mewujudkan tujuan sekolah dan pendidikan.

d. berhasil menerapkan prinsip kepemimpinan yang sesuai dengan tingkat kedewasaan guru dan pegawai lain di sekolah.

e. bekerja dengan tim manajer.

f. berhasil mewujudkan tujuan sekolah secara produktif sesuai dengan ketentuan yang telah ditetapkan. ${ }^{11}$

Pengertian mutu pendidikan

Dalam dunia pendidikan, mutu adalah agenda utama dan senantiasa menjadi tugas yang paling penting. Mutu memiliki persepsi yang berbeda-beda, disesuaikan dengan pandangan masing-masing orang. Para pakar pendidikan pun memiliki kesimpulan yang berbeda tentang bagaimana cara menciptakan lembaga pendidikan yang bermutu baik.

9 H.M Ahmad Rohani dan Abu Ahmadi, Pedoman Penyelenggaraan Administrasi Pendidikan Sekolah, (Jakarta: Bumi Aksara, 1991), h. 94.

${ }^{10}$ E. Mulyasa, KBK, Konsep, Karakteristik dan Implementasi (Bandung: PT. Remaja Rosdakarya, 2003), h. 181.

11 Supriyono, Manajemen Berbasis Sekolah, (Surabaya: SIC, 2001), h. 34. 
Menurut Depdiknas Mutu secara umum didefinisikan sebagai gambaran dan karakteristik menyeluruh dari barang atau jasa yang menunjukkan kemampuannya dalam memuaskan kebutuhan yang diharapkan. ${ }^{12}$ Jerone S. Arcaro Mutu adalah sebuah proses terstruktur untuk memperbaiki keluaran yang dihasilkan. ${ }^{13}$ Menurut Edward Sallis mutu khususnya dalam konteks Total Quality Mnagement (TQM) adalah merupakan sebuah filosofi yang membantu institusi untuk merencanakan perubahan dan mengatur agenda dalam menghadapi tekanantekanan eksternal yang berlebihan. ${ }^{14}$

Madrasah yang bermutu

Berkenaan dengan madrasah/sekolah yang bermutu, ada beberapa model (karakteristik) sekolah bermutu yang dikemukakan oleh Jerome S. Arcoro di antaranya adalah:

a. Fokus pada customer. Dalam meningkatkan penyelenggaraan mutu pendidikan madrasah/sekolah harus melayani kebutuhan customer baik internal maupun eksternal.

b. Keterlibatan total. Semua komponen yang berkepentingan (warga madrasah, warga masyarakat dan warga pemerintah) harus terlibat secara langsung dalam pengembangan mutu pendidikan.

c. Pengukuran. Pengukuran dilakukan dengan cara di evaluasi, evaluasi ini dijadikan acuan dalam meningkatkan penyelenggaraan mutu pendidikan. Salah satu bagian yang sering dijadikan instrumen pengukuran adalah nilai prestasi siswa.

d. Komitmen. Hal lain yang menyangkut pendidikan bermutu adalah adanya komitmen bersama terhadap budaya mutu, utamanya komite madrasah dan pemerintah.

e. Memandang pendidikan sebagai sistem. Pandangan seperti ini akan mengeliminasi pemborosan dari pendidikan dan dapat memperbaiki mutu setiap proses pendidikan.

\footnotetext{
12 Departemen Pendidikan Nasional, Manajemen Peningkatan Mutu Berbasis Sekolah, (Buku I Konsep Dasar) Ditjen Pendidikan Dasar dan Menengah Direktorat Sekolah Lanjut Tingkat Pertama, Edidi IV Revisi: Jakarta, 2002), h. 7.

${ }^{13}$ Jerome. S. Arcaro, Quality in Education: (An Implementation Handbook) Ali Bahasa. Pendidikan Berbasis Mutu (Prinsipprinsip dan Tata Langkah Penerapan), (Yogyakarta: Yosal Iriantara, 2007), h. 75
}

Jurnal Dirasah, Volume 1, Nomor 2, Agustus 2018 f. Perbaikan berkelanjutan. Prinsip dasar mutu adalah perbaikan secara terus menerus (berkelanjutan) langkah ini dilakukan secara konsisten sampai menemukan cara menangani masalah dan membuat perbaikan yang diperlukan. ${ }^{15}$

Perilaku kepala sekolah dalam membangun mutu pendidikan

Tiong dalam Usman, menemukan dalam penelitiannya tentang karakteristik kepala sekolah efektif yang mendukung dalam membangun mutu pendidikan antara lain sebagai berikut. Kepala sekolah yang adil dan tegas dalam mengambil keputusan, membagi tugas secara adil kepada guru, menghargai partisipasi staf, memahami perasaan guru, memiliki visi dan berupaya melakukan perubahan, terampil dan tertib, berkemampuan dan efisien, memiliki dedikasi dan rajin, tulus dan percaya diri ${ }^{16}$

Sedangkan perilaku kepemimpinan kepala sekolah yang tidak efektif antara lain mencerminkan semangat yang rendah, berpandangan sempit, diktator dan tidak memiliki rasa keterlibatan dalam organisasi.

Strategi kepala sekolah dalam membangun mutu pendidikan

Mutu pendidikan, sebagai salah satu pilar pengembangan sumber daya manusia sangat penting maknanya bagi pembangunan nasional. Bahkan dapat dikatakan masa depan bangsa terletak pada keberadaan pendidikan yang berkualitas pada masa kini, pendidikan yang berkualitas hanya akan muncul apabila terdapat lembaga pendidikan yang berkualitas. Karena itu, upaya meningaktkan mutu pendidikan merupakan titik strategi dalam upaya menciptakan pendidikan yang berkualitas.

Di sekolah terdapat dua boss yang paling berperan dan sangat menentukan kualitas pendidikan yakni kepala sekolah dan guru. Dalam perpekstif globalisasi, otonomi daerah, dan desentralisasi pendidikan serta untuk menyukseskan manajemen

\footnotetext{
14 Edward Sallis, Total Quality Management in Education, (Manajemen Mutu Pendidikan) Alih Bahasa. Ahmad Ali Riyadi \& Fahrurrozi. (Yogyakarta: Cet. VII, 2008), h. 33

15 Jerome. Quality in Education., h. 43-44.

16 Huseini Usman, Manajemen: Teori, Praktik, dan Riset Pendidikan, (Jakarta: Bumi Aksara, 2011), h. 290.
} 
berbasis sekolah, kepala sekolah merupakan figure sentral yang harus menjadi teladan bagi para tenaga kependidikan lain di sekolah. Oleh karena itu untuk menunjang keberhasilan dalam perubahanperubahan yang dilakukan dan diharapkan perlu dipersiapkan kepala sekolah yang professional, yang mau dan mampu melakukan perencanaan, pelaksanaan serta evaluasi terhadap berbagai kebijakan dan perubahan yang dilakukan secara efektif dan efisien.

Sehingga kepala sekolah yang professional dituntun untuk mampu membuat strategi yang matang agar bisa membawa lembaga yang dipegangnya menjadi lembaga yang berkualitas. Terutama berkenaan dengan dua figure yang menjadi kunci suksesnya sebuah lembaga pendidikan yaitu kepala sekolah dan guru. SDM yang berkualitas, berpengatahuan luas, menguasai teknologi dan informasi merupakan kunci sukses sebuah lembaga pendidikan. Untuk itu kepala sekolah harus mampu memperbaiki kualitas SDM secara bertahap dan berkesinambungan melalui strategi-strategi yang terencana, agar tercipta SDM yang professional sehingga mampu menciptakan suasana pembelajaran yang berkualitas.

Dengan demikian dapat dipahami bahwa peran kepala sekolah sebagai leader, harus memiliki beberapa kemampuan yang meliputi kemampuan baik dari segi kepribadian, pengetahuan tenaga kependidikan, visi dan misi sekolah, kemampuan mengambil keputusan dan kemampuan berkomunikasi.

Hadits tentang bahaya menyerahkan urusan kepada yang bukan ahlinya, telah ditegaskan oleh Nabi Muhammad shallallahu 'alaihi wa sallam.

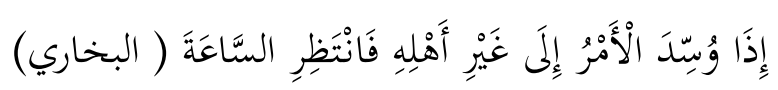

Artinya "Dari abu Hurairah r.a. ia berkata : Rasulullah SAW telah bersabda : Apabila suatu perkara diserahkan kepada orang yang bukan ahlinya maka tunggulah saat kehancurannya" (HR. Bukhari).

Makna hadits tersebut dapat dipahami bahwa betapa pentingnya keahlian yang harus dimiliki seorang kepala sekolah dalam melaksanakan tugastugas yang telah diamanatkannya, karena tugas seorang pemimpin harus dilakukan oleh seorang kepala sekolah yang benar-benar mempunyai ilmu dibidang kependidikan.

Dalam rangka mewujudkan lembaga yang bermutu kepala sekolah memiliki beberapa strategi atau kiat-kiat sukses dalam membangun mutu pendidikan yaitu:

a. Keberanian kepala sekolah melakukan perubahan yaitu memunculkan kepemimpinan yang partisipatif, demokratis dan fleksibel.

b. Berpikir logis dalam melakukan perubahan.

c. Melaksanakan pola kemitraan dalam melakukan perubahan.

d. Pengambilan kebijakan dengan pola partisipatif.

e. Memberikan kebebasan berinovasi kepada warga sekolah.

f. Meningkatkan peran serta masyarakat dalam pendidikan khususnya dalam pembelajaran.

g. Adanya keterlibatan masyarakat dalam perencanaan, pelaksanaan, monitoring dan evaluasi pendidikan.

h. Penerapan pembelajaran aktif, inovatif, kreatif, efektif, dan menyenangkan (PAIKEM). ${ }^{17}$

\section{Metode Penelitian}

\section{Pendekatan dan jenis penelitian}

Dalam penelitian ini, peneliti berperan sebagai instrumen utama pengumpulan data. Instrumen non manusia (dokumentasi) juga dipergunakan, tetapi fungsinya terbatas sebagai pembantu. Jika mengacu pada pendapat Moleong, maka manusia sebagai instrumen utama sangat diperlukan dan sesuai dengan penelitian kualitatif.

Data dan sumber data

Data dan sumber data dalam penelitian ini adalah orang-orang yang dapat memberikan informasi atau keterangan yang berkenaan dengan kebutuhan penelitian, yakni kepala madrasah, wakil kepala madrasah, para tenaga pendidik yang telah mengajar minimal 8 tahun.

\section{Teknik pengumpulan data}

Teknik pengumpulan data dalam penelitian ini adalah dengan menggunakan tiga ( 3 ) pendekatan yaitu: 1) observasi, 2) wawancara, 3) dokumentasi. Instrumen utama dalam penelitian ini adalah peneliti itu sendiri dengan menggunakan alat bantu rekaman, kamera, pedoman wawancara dan sebagainya yang

\footnotetext{
${ }^{17}$ KEMENDIKBUD, Tugas dan peran., h. 710.
} 
berhubungan dengan pengumpulan data yang diperlukan.

\section{Teknik analisis data}

Analisis data yang digunakan dalam penelitian ini adalah analisis data kualitatif terdiri dari: klasifikasi data dan reduksi data, metode analisis dan pembahasan, dan penarikan kesimpulan.

Pengecekan keabsahan data

Selanjutnya teknik yang digunakan untuk memeriksa keabsahan data tersebut adalah triangulasi data.

\section{Paparan Data Dan Temuan Penelitian}

Perilaku kepala sekolah dalam membangun mutu pendidikan

a. Memberi Motivasi

Menurut Abraham Maslow ${ }^{18}$ Motivasi merupakan keadaan kejiwaan dan sikap mental manusia yang memberikan energi, mendorong kegiatan atau gerakan mengarah atau menyalurkan perilaku kearah mencapai kebutuhan yang memberikan keputusan atau mengurangi ketidakseimbangan.

b. Komunikasi yang aik

Menggunakan bahasa komunikasi yang baik hal ini sesuai dengan firman Allah SWT dalam surah Q.S Al-Nisa': 5:

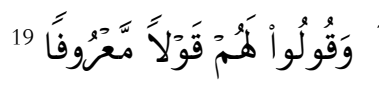

Artinya: "dan ucapkanlah kepada mereka katakata yang baik."

c. Melibatkan seluruh warga sekolah

Sebagaimana dijelaskan dalam Al-Qur'an surah Ali Imron ayat 159 "dan bermusyawaratlah dengan mereka dalam urusan itu". ${ }^{20}$

d. Memberikan keteladanan

Hal itu sesuai dengan wahyu Allah dalam surah Al-Ahzab ayat 21, Rasulullah telah menjadi teladan para shahabatnya, serta menjadi panutan dalam melangkah dan mengarungi samudera yang dahsyat dengan gelombangnya.

\footnotetext{
${ }^{18}$ Abraham H. Maslow, Motivasi dan Kepribadian, (Bandung: PT. Remaja Rosdakarya, 1993), h. 96.

${ }^{19}$ Departemen agama, Al-Qur'an..., h. 100.
}

Strategi kepala sekolah dalam membangun mutu pendidikan

a. Membangun team work

Hal ini sebagaimana dijelaskan dalam AlQur'an surah Al-Maidah ayat 2:

"dan tolong-menolonglah kamu dalam (mengerjakan) kebajikan dan takwa, dan jangan tolong-menolong dalam berbuat dosa dan pelanggaran." 21

b. Membangun kekeluargaan

Hal itu sesuai dengan firman Allah dalam surah Muhammad ayat 22-23, tentang pentingnya menjalin hubungan kekeluargaan:

"Maka Apakah kiranya jika kamu berkuasa kamu akan membuat kerusakan di muka bumi dan memutuskan hubungan kekeluargaan? Mereka Itulah orang-orang yang dila'nati Allah dan ditulikan-Nya telinga mereka dan dibutakan-Nya penglihatan mereka."

Meningkatkan kualitas dan kualifikasi guru

Pendidikan dan pelatihan suatu proses yang akan menghasilkan suatu perubahan perilaku. Secara nyata perubahan perilaku itu berbentuk peningkatan mutu kemampuan dari sasaran pendidikan dan pelatihan.

Pendidikan dan pelatihan pada hakikatnya merupakan salah satu bentuk kegiatan dari program pengembangan sumber daya manusia (personal development).

c. Pembagian tugas sesuai dengan tupoksi dan kemampuan masing-masing bawahan

Sebagaimana dijelaskan dalam Al-Qur'an surah As-Sajadah ayat 24 tentang kemampuan pemimpin dalam memberi pentunjuk dan pembagian tugas:

"Dan Kami jadikan di antara mereka itu pemimpin-pemimpin yang memberi petunjuk dengan perintah Kami ketika mereka sabar. dan adalah mereka meyakini ayat-ayat kami. ${ }^{22}$

d. Bekerja sama dengan lembaga lain

Hal ini sesuai dengan dengan firman Allah tentang menjalin kerja sama menghadirkan hikmah yaitu surah Al-Maidah ayat 2:

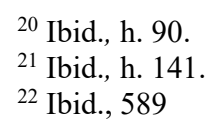


"dan tolong-menolonglah kamu dalam (mengerjakan) kebajikan dan takwa, dan jangan tolong-menolong dalam berbuat dosa dan pelanggaran. dan bertakwalah kamu kepada Allah, Sesungguhnya Allah Amat berat siksa-Nya."23

e. Menjalin kerja sama dengan media massa

Menurut Frank Jefkins dalam buku Public Relations dan Periklanan, fungsi media relations atau press relations adalah menyiarkan atau mempublikasikan seluas-luasnya informasi PR guna menciptakan pengetahuan dan memberi pengertian bagi publiknya. ${ }^{24}$

Dengan menjalin kerjasama dengan media massa mempermudah sekolah dalam menunjukkan bukti-bukti kongkrit kegiatankegiatan maupun prestasi-prestasi siswa baik akdemik maupun nonakdemik.

e. Mempunyai target mutu yang jelas

Lembaga pendidikan yang mempunyai target mutu yang jelas dan terperinci akan lebih mudah untuk mencapai sesuai apa yang direncanakan. Ibarat sebuah mobil yang akan bepergian jauh tentu akan cepat sampai lokasi yang dituju ketika target tujuan sudah jelas dan terperinci.

\section{Temuan Penelitian dan Pembahasan}

Perilaku kepala sekolah dalam membangun mutu pendidikan di MTsN model Pare, Kediri

Kepala sekolah MTsN Model Pare memberikan motivasi dan dorongan kepada para bawahan agar bekerja keras, cerdas dan ikhlas guna mewujudkan lembaga yang bermutu dan berkualitas. Selain itu, kepala sekolah juga membangun komunikasi yang baik dan hangat ke semua lini baik internal maupun eksternal sekolah, serta kepala sekolah juga melibatkan seluruh warga sekolah untuk bersamasama membangun mutu pendidikan unggulan. kepala sekolah MTsN Model Pare dalam memimpin lebih mengedepankan contoh dan teladan, kepala sekolah juga menghormati bawahan, kepala sekolah melakukan silaturahmi kepada bawahan.

\footnotetext{
${ }^{23}$ Ibid., 141

${ }^{24}$ shttp://tika-

knowledgesociety.blogspot.sg/2012/03/keterkaitan-media-
}

Strategi kepala sekolah dalam membangun mutu pendidikan di MTsN model Pare Kab. Kediri

Strategi kepala sekolah dalam membangun mutu pendidikan adalah dengan membentuk team work (yang terdiri dari wakil kepala sekolah, guru dan karyawan) dalam membangun mutu pendidikan, kepala sekolah meningkatkan kegigihan, komitmen kepada bawahan agar meningkatkan kekompakan dalam melaksanakan tugasnya.

Membangun kekeluargaan dalam menciptakan iklim kerja yang kondusif. Kepala sekolah mengadakan silaturahmi, halal bihalal dan piknik kepada bawahan untuk mempererat hubungan kami.

Meningkatkan kualitas dan kompetensi guru dan karyawan, kepala sekolah selalu mensupport dan memberi kemudahan kepada guru-guru dan karyawan yang ingin mengikuti seminar-seminar atau workshop. Kepala sekolah juga membagi tugas sesuai dengan tupoksi dan kemampuan masing-masing bawahan.

Bekerja sama dengan lembaga lain dan media massa, kepala sekolah menjalin kerja sama dengan berbagai pihak lembaga-lembaga di pare maupun diluar pare untuk menjaring siswa-siswa yang berprestasi. Dan juga kepala sekolah menjalin kerja sama dengan pihak media massa seperti Radar Kediri dan Dhoho Tv untuk membantu mempublikasikan bentuk-bentuk kegiatan-kegiatan maupun prestasiprestasi MTsN Model Pare baik akademik maupun nonakdemik.

Mempunyai target mutu yang jelas, kepala sekolah harus mempunyai target mutu yang jelas, sehingga dalam pelaksanaannya kepala sekolah mempunyai goal ( tujuan ) dan sasaran sesuai dengan target yang diinginkan.

Berdasarkan pemaparan hasil penelitian diatas dapat ditemukan temuan lintas situs antar kepala sekolah sebagai berikut:

a. Kedua kepala sekolah menerapkan initiating structure (struktur tugas) dan consideration (tenggang rasa) yaitu: kepala sekolah menerapkan perilaku kepemimpinan yang partisipatif, semua unsur sekolah dilibatkan dalam membangun mutu pendidikan, semua ide yang berasal dari bawahan di tampung sebagi

relations-dengan.html, diakses pada tanggal 08 Desember 2016 pukul 14:24 
pendukung dalam membangun mutu pendidikan, kepala sekolah menontrol dan mengorganisir dalam membangun mutu pendidikan.

b. Dari kedua kepala sekolah tersebut sama-sama memberikan motivasi dan dorongan kepada seluruh warga sekolah untuk bekerja secara profesional serta meningkatkan komitmen pada sekolah.

c. Kedua kepala sekolah juga menjalin komunikasi yang baik dan hangat kepada bawahan baik internal maupun eksternal melalui sharing bersama yaitu kepala sekolah menerima semua usulan yang datang dari bawahan.

d. Kedua kepala sekolah juga melibatkan semua warganya dalam membangun mutu pendidikan.

e. Kedua kepala sekolah juga mengedepankan contoh atau suri tauladan yang baik kepada semua warganya. Kepala sekolah menghormati bawahan, membangun hubungan yang baik kepada bawahan.

f. Kedua kepala sekolah membentuk team work (yang terdiri dari wakil kepala sekolah, guru dan karyawan) dalam membangun mutu pendidikan. Kepala sekolah meningkatkan kegigihan dan komitmen bagi para warga dalam membangun mutu pendidikan yang berkualitas dan unggul.

g. Kedua kepala sekolah membangun kekeluargaan dalam membangun mutu pendidikan. Meningaktkan tali silaturahmi, pendekatan kepada bawahan.

h. Kedua kepala sekolah juga mendukung dan mensupport guru-guru maupun karyawan yang ingin mengikuti studi lanjut maupun seminarseminar dan workshop. Untuk meningkatkan kualitas dan kompetensi para guru dan karyawan.

i. Kedua kepala sekolah juga membagi tugas maupun mendelegasikan guru-guru sesuai dengan tupoksi dan kemampuan masing-masing bawahan, kepala sekolah memberikan kepercayaan penuh dalam proses pembangunan mutu pendidikan.

j. Kepala sekolah lebih fokus pada perkembangan internal sekolah daripada memanfaatkan kemajuan teknologi. Sedangkan kepala sekolah yang sekarang mengkolaborasikan keduanya. Yaitu meningkatkan internal tetapi juga memanfaatkan perkembangan teknologi salah satunya kepala sekolah menjalin kerjasama dengan Radar Kediri. Radar Kediri akan menerbitkan setiap sebulan sekali satu lembar penuh yang berisi tentang prestasi-prestasi maupun rangkaian kegiatan-kegiatan madrasah. Disamping Radar Kediri kepala sekolah juga menjalin hubungan dengan Dhoho TV meskipun tidak serutin dengan Radar Kediri.

k. Kedua kepala sekolah di atas juga mempunyai target mutu yang jelas. Sehingga memudahkan kepala sekolah dalam mencapai target atau sasaran karena ada goal atau tujuan yang diinginkan.

\section{Kesimpulan}

Hasil penelitian ini menyimpulkan bahwa:

1. Perilaku kepala sekolah dalam membangun mutu pendidikan yaitu; memberi motivasi; menjalin komunikasi yang baik dan hangat; melibatkan semua warga sekolah; dan memberikan keteladanan bagi warga sekolah dalam upaya membangun mutu pendidikan.

2. Strategi kepala sekolah dalam membangun mutu pendidikan yaitu membangun team work yang kaut dan solid; membangun kekeluargaan; mendukung dan mempermudah guru dalam pengembangan kualitas dan kompetensi; pembagian kinerja sesuai tugas pokok dan fungsi dan kemampuan masing-masing bawahan; bekerja sama dengan lembaga lain; menjalin kerja sama dengan media massa; serta mempunyai target mutu yang jelas.

\section{Daftar Pustaka}

Abraham H. Maslow. 1993. Motivasi dan Kepribadian, Bandung: PT. Remaja Rosdakarya

Arcaro, Jerome. S. Quality in Education: (An Implementation Handbook) Ali Bahasa. Pendidikan Berbasis Mutu (Prinsip-prinsip dan Tata Langkah Penerapan), Yogyakarta: Yosal Iriantara. 2007.

Departemen Agama. Al-Qur'an dan Terjemahnya, Jakarta: CV. Khatoda. 2005.

Departemen Pendidikan Nasional. Manajemen Peningkatan Mutu Berbasis Sekolah, (Buku I Konsep Dasar) Ditjen Pendidikan Dasar dan 
Menengah Direktorat Sekolah Lanjut Tingkat Pertama, Edidi IV Revisi: Jakarta. 2002.

Dokumentasi, sejarah singkat MTsN Model Pare

Hasil wawancara dengan kepala sekolah MTsN Model Pare oleh bapak Jamiluddin, pada tanggal 8 Agustus 2016

Kamus besar bahasa Indonesia. Departemen Pendidikan dan Kebudayaan Republik Indonesia, Jakarta: Perum Balai Pustaka. 1988.

KEMENDIKBUD, Tugas dan peran kepala sekolah dalam manajemen kurikulum

M. Saroni M. Manajemen Sekolah Kiat Menjadi Pendidik Yang Kompeten, Jogjakarta: Ar-Ruzz Media. 2002.

Maslow, Abraham H. Motivasi dan Kepribadian, Bandung: PT. Remaja Rosdakarya, 1993.

Mulyasa, E. KBK, Konsep, Karakteristik dan Implementasi, Bandung: PT. Remaja Rosdakarya. 2003.

Rohani, H.M Ahmad dan Abu Ahmadi. Pedoman Penyelenggaraan Administrasi Pendidikan Sekolah. Jakarta: Bumi Aksara. 1991.
Sallis, Edward. Total Quality Management in Education, Manajemen Mutu Pendidikan) Alih Bahasa. Ahmad Ali Riyadi \& Fahrurrozi. Yogyakarta: Cet. VII. 2008.

Supriyono. Manajemen Berbasis Sekolah, Surabaya: SIC. 2001.

Tannenbaun, Weschler dan Massarik. F. Leadership and Organisation, New York: McGraw-Hill. 1961.

Usman, Huseini. Manajemen: Teori, Praktik, dan Riset Pendidikan, Jakarta: Bumi Aksara. 2011.

Wahjosumidjo. Kepemimpinan Kepala Sekolah, Jakarta: Raja Grafindo. 1999.

http://tika-

knowledgesociety.blogspot.sg/2012/03/keterka itan-media-relations-dengan.html, di akses pada tanggal 08 Desember 2016 pukul 14:24

http://tika-

knowledgesociety.blogspot.sg/2012/03/keterka itan-media-relations-dengan.html, di akses pada tanggal 08 Desember 2016 pukul 14:24

Copyright (C) 2018 Journal Dirasah: Vol. 1, No. 2, August 2018, p-ISSN: 2615-0212, e-ISSN; 26212838

Copyright rests with the authors

Copyright of Jurnal Dirasah is the property of Jurnal Dirasah and its content may not be copied or emailed to multiple sites or posted to a listserv without the copyright holder's express written permission. However, users may print, download, or email articles for individual use.

https://ejournal.stisfa-kediri.ac.id/index.php/dirasah 